https://doi.org/10.52058/2708-7530-2021-3(9)-180-192

Пархоменко-Куцевіл Оксана Ігорівна доктор наук 3 державного управління, професор, завідувач кафедри публічного управління та адміністрування Переяслав-Хмельницького державного педагогічного університету імені Григорія Сковороди, вул. Сухомлинського, 30, Переяслав, 08400, тел.: (096) 703-12-71, e-mail: pkoi@ukr.net, https://orcid.org/0000-0002-0758$346 \mathrm{X}$

Корчак Наталія Миколаївна доктор юридичних наук, доцент, заслужений юрист України, професор кафедри державного управління, Київський національний університет імені Тараса Шевченка, вулиця Володимирська, 60, Київ, 01033, тел.: (044) 239-32-20, e-mail: nkorchak15@gmail.com, https://orcid.org/0000-0001-7702-2636

\title{
МЕХАНІЗМИ РЕІНЖИНІРИНГУ В СИСТЕМІ ФОРМУВАННЯ ІННОВАЦІЙНИХ АНТИКОРУПЦІЙНИХ ОРГАНІВ ДЕРЖАВНОЇ ВЛАДИ: ТЕОРЕТИЧНИЙ АСПЕКТ
}

Анотація. Мета статті полягає у системному аналізу процесів реінжинірингу при реформування антикорупційних органів державної влади. У статті обгрунтовано, що реінжиніринг - методологічна основа формування інноваційних антикорупційних органів на підставі грунтовного аналізу функціональних обов'язків новостворених антикорупційних інституцій та формування залежно від виконуваних функцій державних органів влади у сфері запобігання та боротьби 3 корупцією. На нашу думку, 3 урахуванням реінжинірингу потрібно переформатувати антикорупційні органи державної влади у дві складові: формування механізмів запобігання корупції та реалізація механізмів боротьби 3 корупцією. Водночас, реінжиніринг адміністративних процесів - архітектурна побудова, створення державних установ (закладів, організацій) на основах інженерної науки шляхом проектування й управління державними процесами. Доведено, що до основних етапів реінжинірингу адміністративних процесів належать: підготовчий етап, який включає: репозиціювання, визначення головної місії та основних проблем функціонування; етап стратегічного планування процесу реінжинірингу адміністративних процесів; етап розробки проекту реінжинірингу адміністративних процесів; етап реалізації й контролю реінжинірингу адміністративних процесів. 
Наукова новизна статті полягає у проведенні системному аналізу процесів реінжинірингу при реформування антикорупційних органів державної влади.

Практична значимість статті пов'язана з можливістю реформування систему органів державної влади, які реалізують антикорупційну політику в Україні.

Обгрунтовано, що 3 урахуванням реінжинірингу доцільно провести моніторинг інституційної діяльності антикорупційних органів, зробити висновки щодо загальної ефективності системи протидії корупції, у якій кожен із органів має часткову роль, та, за необхідності, підготувати пропозиції стосовно оптимізації повноважень антикорупційних органів задля удосконалення механізмів: 1) запобігання корупції (напрямок загальної превенції); 2) боротьби 3 корупцією (репресивно-каральний напрямок).

Правовий концепт протидії корупції в Україні можна проілюструвати у такий спосіб: запобігання - розслідування - кримінальне переслідування за корупцію призупинення операцій, арешт, конфіскація та повернення доходів від корупційних злочинів.

Ключові слова: публічне управління; корупція; реінжиніринг; антикорупційні органи державної влади; механізми реформування та модернізації органів державної влади.

Parkhomenko-Kutsevil Oksana Ihorivna Doctor of Science in Public Administration, Professor, Professor of the Department of Public Administration, Interregional Academy of Personnel Management (Ukraine), Sukhomlinskoho St., 30, Pereyaslav, 08400, tel.: (096) 703-12-71, e-mail: pkoi@ukr.net, https://orcid.org/00000002-0758-346X

Korchak Nataliia Mykolaivna Doctor of Law, Associate Professor, Professor of the Public Administration Department, Taras Shevchenko National University of Kyiv, Volodymyrska St., 60, Kyiv, 01033, tel.: (044) 239-32-20, e-mail: nkorchak15@gmail.com, https://orcid.org/0000-0001-7702-2636

\section{REENGINEERING MECHANISMS IN THE SYSTEM OF FORMATION OF INNOVATIVE ANTI-CORRUPTION PUBLIC AUTHORITIES: THEORETICAL ASPECT}

Abstract. The purpose of the article is to systematically analyze the reengineering processes in reforming anti-corruption public authorities.

The article substantiates that reengineering is a methodological basis for the formation of innovative anti-corruption bodies based on a thorough analysis of the functional responsibilities of newly established anti-corruption institutions and the formation, 
depending on the functions of public authorities in preventing and combating corruption. In our opinion, taking into account reengineering, it is necessary to reformat the anti-corruption public authorities into two components: the formation of mechanisms to prevent corruption and the implementation of mechanisms to combat corruption. At the same time, reengineering of administrative processes - architectural construction, creation of state institutions (institutions, organizations) on the basis of engineering science through the design and management of state processes.

The authors proved that the main stages of reengineering of administrative processes include: the preparatory stage, which includes: repositioning, defining the main mission and the main problems of functioning; stage of strategic planning of the process of reengineering of administrative processes; stage of development of the project of reengineering of administrative processes; stage of implementation and control of reengineering of administrative processes.

The scientific novelty of the article is a systematic analysis of reengineering processes in the reform of anti-corruption public authorities.

The practical significance of the article is related to the possibility of reforming the system of public authorities that implement anti-corruption policy in Ukraine.

The article substantiates that, taking into account reengineering, it is expedient to monitor the institutional activities of anti-corruption bodies, draw conclusions about the overall effectiveness of the anti-corruption system, in which each body has a partial role, and, if necessary, prepare proposals to optimize the powers of anti-corruption bodies. 1) prevention of corruption (direction of general prevention); 2) fight against corruption (repressive and punitive direction).

The legal concept of combating corruption in Ukraine can be illustrated as follows: prevention - investigation - prosecution of corruption - suspension of operations, arrest, confiscation and return of proceeds from corruption crimes.

Keywords: public administration, corruption, reengineering, anti-corruption public authorities, mechanisms of reforming and modernizing public authorities.

Постановка проблеми. На сьогодні спостерігається активне формування та розвиток антикорупційних органів державної влади, які мають формувати та реалізовувати ефективну антикорупційну політики в України. Разом 3 тим, становлення цих державних органів відбувається повільне без визначення єдиної стратегічної мети та реальних етапів розвитку. Крім того, спостерігається дещо спотворена комунікація між новоствореними антикорупційними інституціями. Деякі антикорупційні інституції дублюють функції один одного або деякі функції щодо реалізації антикорупційної політики не охоплені такими державними інституціями. Тому виникла потреба у формуванні антикорупційних органів відповідно до вимог реінжинірингу. 
Формування антикорупційних інституцій за допомогою реінжинірингу надасть можливість сформувати єдину систему антикорупційних органів, метою яких буде формування та реалізація єдиної антикорупційної політики.

На початку дослідження процесі реінжинірингу в системі формування антикорупційних органів державної влади, розглянемо основні наукові підходи до поняття «реінжиніринг» та його зміст в системі функціонування будь-якої бізнесструктури. Існує багато визначень поняття «реінжиніринг», розглянемо базові 3 них.

Аналіз останніх досліджень і публікацій. Основні підходи щодо теоретичного обгрунтування та практичного втілення реінжинірингу в адміністративні процеси, у тому числі в систему публічного управляння аналізують: О. Бабак [1], А. Блінов [2], О. Виноградова [3], М. Гончарова [4], В. Захаров [2], О. Розкошна [4], О. Рудакова [2], Хаммер М. [5], Л. Шейн [6], С. Яковенко [7] та інші. Зазначені автори розглядають проблеми реалізації механізмів реінжинірингу як основи розбудови адміністративних процесів.

Постановка завдання. На підставі результатів попередніх наукових досліджень завдання дослідження є системний аналіз процесів реінжинірингу при реформування антикорупційних органів державної влади.

Виклад основного матеріалу. Теоретичні аспекти впровадження реінжинірингу розроблені американськими вченими М. Хаммером та Дж. Чампі у 80-ті рр. ХX ст., які вперше сформулювати дефініцію «реінжиніринг». Так, реінжиніринг - це фундаментальне переосмислення та радикальне перепроектування бізнес-процесів із метою досягнення істотного поліпшення у таких ключових для сучасного бізнесу показниках результативності, як витрати, якість, рівень обслуговування та оперативність. Основними в реінжинірингу є дві проблеми: радикальне проектування та бізнесові процеси [5]. Це полягає, зокрема, у переорієнтації від функції на шляхи інтегрованих реалізаційних процедур, що вимагає зміни існуючих правил просування в багатьох сферах організації. Якщо керівництво підприємства зважилося на такі дії, а працівники відповідно підготовлені до цього, то існує великий шанс вдосконалити організацію i, одночасно з цим, здобути перемогу над конкурентами.

Окремі вчені розглядають поняття «реінжиніринг» як:

- реконструювання або створення нових бізнес-процесів з метою підвищення ефективності діяльності підприємства. Відмітною рисою цього підходу, порівняно 3 іншими методами процесного управління, $\epsilon$ спрямованість на кардинальну зміну бізнес-процесів, а не на поступове їх поліпшення [1];

- проектування компанії відповідно до іiі процесів, в не згідно 3 спеціалізованими структурними підрозділами компанії [2];

- науково-практичний підхід до кардинального перепроектування бізнес- 
процесів підприємства для стабілізації та росту його господарської діяльності за рахунок виявлення проблемних, «критичних зон» та вживання заходів по їх усуненню [3];

- сукупність методів і засобів, призначених для кардинального поліпшення основних показників діяльності підприємства шляхом моделювання, аналізу, перепроектування вже існуючих бізнес-процесів [4, с. 103];

- інструмент, спеціально створений для здійснення масштабних змін в управлінні процесами, які не можуть бути забезпечені відомими методами удосконалення [7];

- рішучу, стрімку і глибоку «проривну» перебудову основ внутріфірмової організації та керування [6].

Таким чином, реінжиніринг бізнес-середовища пов’язують 3 процесами реструктуризації та базується на інженерному підході до процесу управління $\mathrm{i}$ передбачає спочатку моделювання організації, а потім зміну існуючої моделі шляхом рішучого скасування нераціонально функціонуючих ланок. Вся сутність реінжинірингу побудована на системі докорінних перетворень в організації. Водночас, реінжиніринг пов'язаний з трансформацією системи управління та іï оптимізацією.

Від реінжинірингу, як методу реорганізації бізнесу за допомогою докорінної перебудови бізнес-процесів, управлінська думка перейшла до поняття «бізнесінжиніринг», тобто до архітектурної побудови, створення бізнесу на основах інженерної науки шляхом проектування й управління бізнес-процесами. Тому, реінжиніринг, як техніка реконструювання бізнес-процесів, став складовою частиною бізнес-інжинірингу [8].

На нашу думку, більш відповідно запровадити у практику формування інноваційних державних інституцій поняття «реінжиніринг адміністративних процесів», під яким розуміється архітектурна побудова, створення державних установ (закладів, організацій) на основах інженерної науки шляхом проектування й управління державними процесами.

Основними функціями реінжинірингу адміністративних процесів є наступні:

- раціоналізація управлінських процесів;

- орієнтованість на надання адміністративних послуг населенню, що в свою чергу, забезпечує якісне надання цих послуг;

- підвищення ролі рішень та ініціативи кожного працівника;

- зниження кількості осіб, які займаються контролем виконання рішень;

- забезпечення прискореного впровадження інноваційних управлінських технологій.

Метою реінжинірингу адміністративних процесів $є$ не перебудова структур органів державної влади, а забезпечення підвищення ефективності роботи 
цих органів влади, істотне поліпшення показників діяльності.

Базовими принципами реінжинірингу адміністративних процесів $\epsilon$ : об’єднання декількох робочих процедур в одну; виконавці приймають самостійні рішення; процеси мають різні варіанти виконання; робота виконується в тому місці [3].

Основними принципами реінжинірингу адміністративних процесів $\epsilon$ наступні. По-перше, оптимізація - кілька процесів (функцій) поєднуються в одну. По-друге, самостійність - виконавці самостійно в межах своїх процесуальних функцій приймають рішення. По-третє, відповідальність, збільшення відповідальності осіб, які приймають рішення. По-четверте, контроль зменшення контролю за поточними процесами, збільшення контролю за результатом.

У концепції реінжинірингу ми перевертаємо модель процесу або органу влади на 180 градусів. Для задоволення сучасних вимог, процеси повинні залишатися простими. Така необхідність спрощення процесів має величезний вплив на те, як вони проектуються і як будуються самі організації [5, с. 88-90].

Тенденції або характеристики адміністративних процесів, які пройшли реінжиніринг.

1) Кілька робіт об'єднуються в одну.

Не завжди можливо звести всі етапи тривалого процесу в одне інтегроване трудове завдання, яке виконує одна людина. В деяких ситуаціях різні етапи процесу повинні здійснюватися в різних місцях. У цих випадках потрібні кілька людей, кожен з яких виконував би окремі елементи процесу. В інших ситуаціях може виявитися недоцільним навчати одну людину всім навичкам, які знадобляться йому для виконання всього процесу цілком.

2) Рішення приймають працівники.

Організації, які реалізують реінжиніринг, утискають свої процеси не тільки по горизонталі, шляхом використання ситуаційних працівників або ситуаційних команд, що виконують численні послідовні завдання, але також і по вертикалі. Вертикальне стиснення означає, що тепер на тих стадіях процесу, де працівники зазвичай були змушені звертатися за відповіддю на виникаючі у них питання до вищестоящих менеджерів, вони самі приймають рішення. Ухвалення рішень не відокремлене від реальної роботи, а стає їі частиною.

3) Етапи процесу виконуються в природному порядку.

Процеси, які пройшли реінжиніринг, вільні від диктату прямолінійної послідовності їх етапів, і в роботі може використовуватися їх природний, а не штучний, нав'язаний лінійністю, порядок.

4) Процеси мають безліч варіантів

Четверту загальну характеристику процесів ми можемо назвати «кінцем 
стандартизації». Всі ресурси використовувалися однаково, 3 тим щоб компанії могли виробляти уніфіковану i мало що змінюється продукцію. У світі різноманітних і мінливих ринків ця логіка стала застарілою. Для того щоб задовольнити вимогам сучасної господарської середовища, необхідно безліч варіантів одного і того ж процесу, кожен з яких був би змінений відповідно до вимог конкретних ринків, ситуацій або ресурсів. Більш того, ці нові процеси повинні давати таку ж економію на масштабі, як і при масовому виробництві.

5) Скорочується обсяг перевірок і контролю [5, с. 88-90].

Перевірки i контроль - інший тип роботи, що не додає вартості i мінімізується в процесах, які пройшли реінжиніринг, або в процесах, які пройшли реінжиніринг, контроль використовується тільки в тій мірі, в якій має економічний сенс.

6) Мінімізується необхідність погоджень.

Дана мінімізація відбувається за рахунок скорочення числа контактів із зовнішнім середовищем. Таким чином знижується ймовірність того, що буде отримана суперечлива інформація, яка потребує погодження [5, с. 98].

7) Ситуаційний менеджер - єдиний контакт із зовнішнім середовищем. Даний механізм виявляється корисний, коли етапи процесу або настільки складні, або настільки розрізнені, що інтегрувати їх в обов'язки однієї особи, або навіть невеликої групи неможливо. Ситуаційний менеджер, який діє як буфер між все ще складним процесом і середовищем, веде себе 3 останнім так, як ніби він відповідає за здійснення всього процесу, хоча насправді це не так . Для виконання даної ролі, тобто для того, щоб бути в змозі відповісти на питання і вирішити проблеми, ситуаційному менеджеру необхідні доступ до інформаційних систем, які використовують люди, які безпосередньо здійснюють процес, а також можливість звертатися до них із запитаннями та проханнями про сприяння в міру їх появи.

8) Переважають змішані централізовані / децентралізовані операції [5, с. 99-100].

На основі практики реінжинірингу в приватному секторі можна сформувати такі можливі принципи реінжинірингу адміністративних процесів:

1. Позбавлятися стереотипів і розглядати систему державного управління поглядом конструктора і архітектора. Одне з ключових понять, що складає основу реінжинірингу адміністративних процесів, - це процеси, а в даному випадку адміністративні процеси. Саме їхня оптимізація і вдосконалення дають змогу відкрити і використати нові можливості, резерви й ресурси розвитку й підвищення ефективності управління.

2. Переходити від управління адміністративними функціями - до управління адміністративними процесами й цілями. Для виконання такого масштабного завдання необхідно застосовувати новаторські підходи й сучасні прийоми i технології управління. 
3. Підтримувати актуальний «дизайн» адміністративних процесів, постійно їх удосконалювати й пристосовувати до умов, що змінюються. Реінжиніринг адміністративних процесів дає можливість не лише управляти виробничими процесами, а й заново їх створювати, якісно моделювати і видозмінювати, вибудовуючи в єдину цілісну й ефективну систему.

4. Проводити постійний моніторинг і аналіз адміністративних процесів та здійснювати пошук і вироблення їхньої оптимальної моделі. Модель адміністративного процесу (реального чи бажаного) завдяки наочності його опису дає можливість проаналізувати, наскільки ефективно він сприяє досягненню визначених цілей і результатів. Оперативними інструментами процесного аналізу в системі державного управління можуть бути логістика адміністративного процесу, його тривалість і вартість (в тому числі його розподіл на окремі етапи), а також інші чинники, від яких залежить або може залежати ефективність його виконання.

5. Чітко й постійно орієнтуватися на зміст самого поняття «процес». Процес - це послідовність виконання функцій (робіт, операцій), спрямованих на досягнення результату, який має цінність і корисність для його споживача. На основі такого визначення кожен процес, в тому числі й адміністративний, можна розділити на його різні складові елементи й функціональні характеристики [8]. Загальну схему проведення реінжинірингу адміністративних процесів можна уявити таким чином: аналіз і побудова моделі «як воно є», побудова можливих моделей реінжинірингу адміністративних процесів, впровадження пріоритетної моделі реінжинірингу адміністративних процесів, здійснення оцінювання результатів проведення реінжинірингу адміністративних процесів.

Загальна схема впровадження реінжинірингу адміністративних процесів відображена на рис. 1.

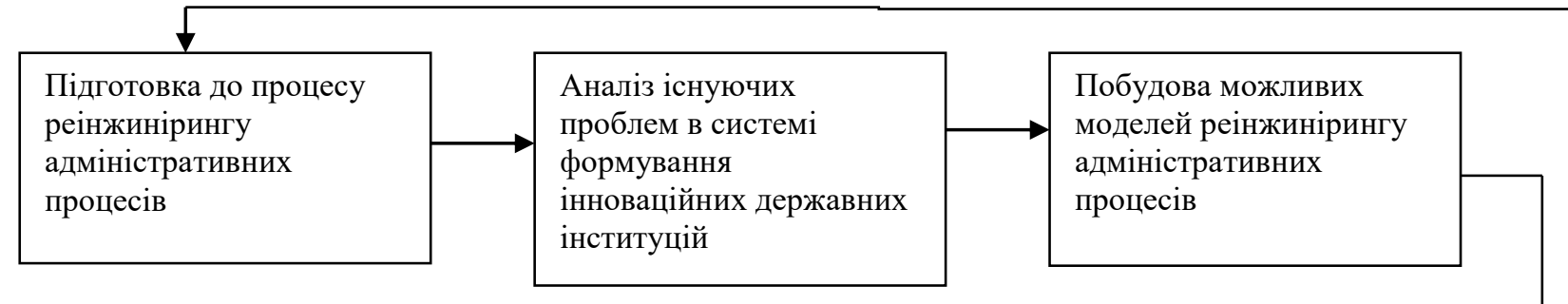

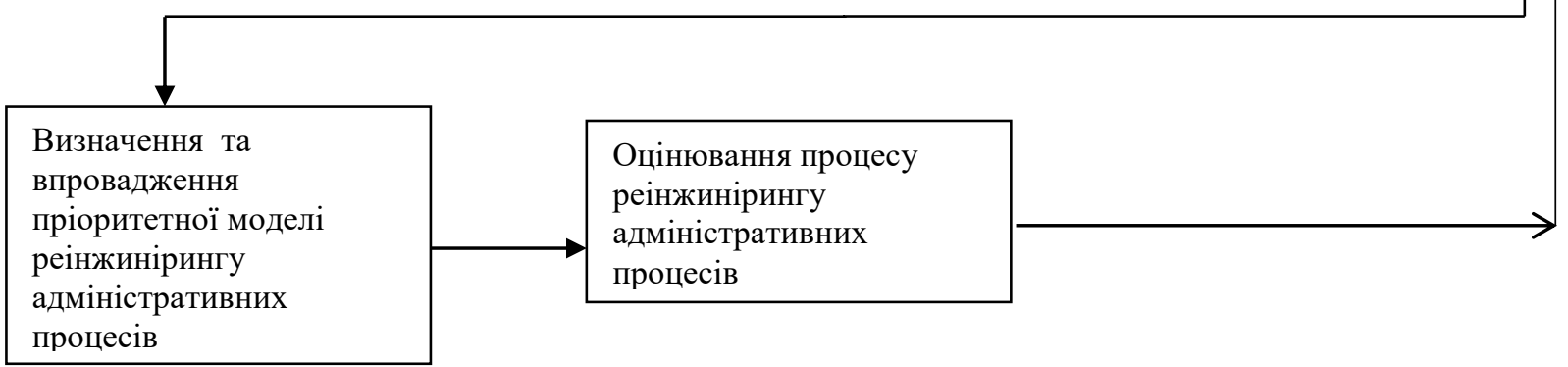

Рис. 1. Технологія реалізації реінжинірингу адміністративних процесів. 
Основними етапами реінжинірингу адміністративних процесів повинні стати наступні. Перший етап: підготовчий етап, який включає: репозиціювання, зокрема визначення ролі, функцій закладу (установи, організації), проведення аудиту основних напрямів діяльності закладу, визначення ролі ресурсів (фінансових, кадрових, інформаційних, інтелектуальних тощо). Саме на цьому етапі визначається головна місія закладу (установи, організації). На першому етапі визначаються основні проблеми функціонування закладу (установи, організації), а також виявляється дублювання функцій [9, с. 20-27].

Наступний (другий) етап - стратегічне планування реінжинірингу адміністративних процесів. На цьому етапі здійснюється відбір та оцінка процесів, реінжиніринг яких є найбільш доцільним та ефективним.

Третій етап - розробка проекту реінжинірингу адміністративних процесів, де визначається: перепроектування обраних процесів; здійснюється розподіл зон відповідальності; визначається бюджет проекту; здійснюється обрання найкращого варіанту серед проектних концепцій. На цьому етапі здійснюється прогнозування майбутніх результатів. Прогнозування повинно передбачати визначення переліку основних внутрішніх процесів, особливостей використання ресурсного потенціалу, досягнення певного рівня ефективності.

Четвертий етап - це реалізація й контроль реінжинірингу адміністративних процесів. На цьому етапі необхідно передбачити етапи моніторингу реінжинірингу адміністративних процесів, відповідальність, звітування, корегування проектної концепції реінжинірингу адміністративних процесів. Крім того, саме на цьому етапі слід врахувати можливості здійснення реінжинірингу адміністративних процесів (ресурси, політична підтримка, реальна реалізація, ефективність та результативність) [9, с. 20-27].

Реінжиніринг адміністративних процесів пов'язують 3 процесами реструктуризації та базується на інженерному підході до процесу управління i передбачає спочатку моделювання організації, а потім зміну існуючої моделі шляхом рішучого скасування нераціонально функціонуючих ланок. Вся сутність реінжинірингу побудована на системі докорінних перетворень в організації. Водночас, реінжиніринг пов'язаний з трансформацією системи управління та іï оптимізацією [9, с. 20-27].

Реінжиніринг адміністративних процесів - архітектурна побудова, створення державних установ (закладів, організацій) на основах інженерної науки шляхом проектування й управління державними процесами.

До основних етапів реінжинірингу адміністративних процесів належать: підготовчий етап, який включає: репозиціювання, визначення головної місії та основних проблем функціонування; етап стратегічного планування процесу реінжинірингу адміністративних процесів; етап розробки проекту реінжинірингу 
адміністративних процесів; етап реалізації й контролю реінжинірингу адміністративних процесів.

Висновки. Тема корупції $є$ суспільно значущою не тільки для України. Політика й практика запобігання та протидії корупції обумовили спрямованість та зміст положень Конвенції ООН проти корупції, яка за результатами їі ратифікації 31 січня 2010 року стала невід’ємною частиною вітчизняного законодавства.

У світі не існує універсальної інституційної моделі спеціалізованого антикорупційного органу чи системи органів з точки зору їх повноважень у галузі протидії корупції. При вирішенні проблеми корупції, кожна країна обирає для себе стратегію (зокрема, виходячи або 3 паритетності заходів 3 боротьби (репресивно-каральне спрямування) та запобігання корупції чи домінування одного з них) протидії цьому явищу і ставить за мету побудову життєздатної системи антикорупційних органів.

Розпочинаючи 32015 року Україна пішла по шляху створення антикорупційних інституцій за принципом розмежування повноважень iз запобігання корупції (загальної превенції їі проявам) та боротьби з нею (боротьби 3 наслідками вчинення корупційних дій за допомогою правоохоронних заходів). Органи прокуратури, Національної поліції, Національне антикорупційне бюро України, Національне агентство з питань запобігання корупції Законом України «Про запобігання корупції» від 14 жовтня 2014 року № 1700-VII визначені як спеціально уповноважені суб’єкти у сфері протидії корупції. На відміну від перших трьох органів, саме Національне агентство забезпечує формування та реалізує державну антикорупційну політику та реалізує виключно повноваження iз запобігання, в тому числі виявлення, корупції.

Незважаючи на нормативну регламентацію діяльності зазначених вище органів, нажаль законодавець не уникнув перетинання в їх діяльності певних антикорупційних функцій. Наприклад, відповідно до п.5 ч.1 ст. 16 та п.11 ч.1 ст. 17 Закону України «Про Національне антикорупційне бюро України» від 14 жовтня 2014 року № 1698-VII [10] цей орган здійснює інформаційно-аналітичну роботу з метою виявлення та усунення причин і умов, що сприяють вчиненню корупційних правопорушень, а також надсилає державним органам, органам місцевого самоврядування обов'язкові до розгляду пропозиції та рекомендації. А виявлення причин та умов -це ніщо інше, як попередження (профілактика) правопорушень. Це з одного боку.

3 іншого, окремі повноважень Національного агентства 3 питань запобігання корупції неможливо ефективно реалізувати без застосування певних правоохоронних засобів. Наприклад, це стосується захисту викривача, проведення повної перевірки щорічної декларації в частині доведення факту користування майном чи наявності сімейних відносин в умовах громадянського шлюбу, або ж 
проведення моніторингу способу життя суб’єкта декларування.

Проведений аналіз дає підстави зазначити, що реінжиніринг - методологічна основа для підготовки науково-обгрунтованої концепції розбудови життєздатної системи органів попередження та боротьби з корупцією з урахуванням іiі межі в країні та співвідношення ресурсів, що має виділити держава для цілей протидії корупції у порівнянні з ресурсами, що будуть відвойовані у корупції на користь українського суспільства (держави) в цілому та, зокрема, специфіки функціональних повноважень створених антикорупційних інституцій.

На нашу думку, з урахуванням реінжинірингу доцільно провести моніторинг інституційної діяльності антикорупційних органів, зробити висновки щодо загальної ефективності системи протидії корупції, у якій кожен із органів має часткову роль, та, за необхідності, підготувати пропозиції стосовно оптимізації повноважень антикорупційних органів задля удосконалення механізмів: 1) запобігання корупції (напрямок загальної превенції); 2) боротьби $з$ корупцією (репресивно-каральний напрямок).

Для формування завершеного уявлення про систему антикорупційних органів в Україні використаємо функціональні аспекти їхньої діяльності:

- функцію по запобіганню корупції виконує виключно Національне агентство з питань запобігання корупції;

- репресивно-каральні функції боротьби 3 корупцією виконують: Національне антикорупційне бюро України; Спеціалізована антикорупційна прокуратура; Державне бюро розслідувань; Національна поліція; органи прокуратури; Національне агентство 3 розшуку та управління активами, одержаними від корупційних та інших злочинів; Вищий антикорупційний суд України.

Правовий концепт протидії корупції в Україні можна проілюструвати у такий спосіб: запобігання - розслідування - кримінальне переслідування за корупцію призупинення операцій, арешт, конфіскація та повернення доходів від корупційних злочинів. Без перебільшення можна стверджувати, що реінжиніринг - це той інноваційний процес, який здатний забезпечити досягнення цілей ефективної скоординованої політики протидії корупції, проведення оцінки відповідних правових інструментів й адміністративних заходів 3 метою визначення їхньої адекватності з точки зору запобігання корупції та боротьби 3 нею, а також зниження загального толерування рівня корупції в Україні i добровільної відмови від корупційних практик.

На сьогодні очевидним $є$ факт зростання репресивно-каральної системи в механізмі протидії корупції без обгрунтування та оцінки ефективності роботи антикорупційних органів правоохоронного прямування та без проведення аналізу очікуваного результату. Тому використання інструментарію реінжинірингу на 
сьогодні є вкрай актуальним.

\section{Лimepamypa:}

1. Бабак О.А. Реінжиніринг як сучасний інструмент інноваційної діяльності підприємств. URL: http://archive.nbuv.gov.ua/portal/soc_gum/evu/2011_17_1/Babak.pdf

2. Блинов А. О., Рудакова О.С., Захаров В. Я. Реинжиниринг бизнес-процессов. М. : Юнити-дана, 2010. 343 с.

3. Виноградова О.В. Реінжиніринг бізнес-процесів у сучасному менеджменті: Монографія. Донецьк, 2005. 195 с.

4. Розкошна О.А., Гончарова М.Л. Особливості формування системи реінжинірингу бізнес-процесів . Академічний огляд. 2011. № 1 (34). С. 103.

5. Хаммер М.,Чампи Дж. Реинжиниринг корпорации. Манифест революции в бизнесе. М. : Изд-во Манн, Иванов и Фербер. 2007. 288 с.

6. Шейн Л. Реинжиниринг бизнес-процессов: модное лекарство? Управление компанией. 2002. № 6. С. 68-74.

7. Яковенко С. I. Реінжиніринг бізнес-процесів шляхом інформатизації управління на підприємствах України. Актуальні проблеми економіки. 2004. № 9 (39). С. 45-53.

8. Можливі принципи й орієнтовані правила проведення адміністративного реінжинірингу URL: http:// library.if.ua/book/44/3048.html

9. Пархоменко_Куцевіл О.І. Сучасні тенденції розвитку реінжинірингу в системі державного управління. Ефективність державного управління. 2013. Вип. 36. С. 20-26.

10. Закон України «Про Національне антикорупційне бюро України». URL: https://zakon.rada.gov.ua/laws/show/1698-18.

\section{References:}

1. Babak O.A. (2011) Reinzhynirynh yak suchasnyi instrument innovatsiinoi diialnosti pidpryiemstv [Reengineering as a modern tool of innovative activity of enterprises.]. URL: http://archive.nbuv.gov.ua/portal/soc_gum/evu/2011_17_1/Babak.pdf [in Ukraine].

2. Blynov A. O. , Rudakova O.S. and Zakharov V. Ya. (2010). Reynzhynyrynh byznesprotsessov [Reengineering of business processes]. M. : Yunyty-dana. [in Russian].

3. Vynohradova O.V. (2005) Reinzhynirynh biznes-protsesiv u suchasnomu menedzhmenti [Business process reengineering in modern management]: Monohrafiia. Donetsk. [in Ukraine].

4. Rozkoshna O.A. and Honcharova M.L. (2011). Osoblyvosti formuvannia systemy reinzhynirynhu biznes-protsesiv [Features of formation of system of reengineering of business processes]. Akademichnyi ohliad - Academic review. (1) (34). [in Ukraine].

5. Khammer M. and Champy Dzh. (2007) Reynzhynyrynh korporatsyy. Manyfest revoliutsyy v byznese [Reengineering Corporation. Manifesto of the Revolution in Business]. M. : Yzd-vo Mann, Yvanov y Ferber. [in Russian].

6. Shein L.(2002) Reynzhynyrynh byznes-protsessov: modnoe lekarstvo? [Business Process Reengineering: A Trendy Cure?]. Upravlenye kompanyei - Company management. (6): 68-74. [in Russian].

7. Iakovenko S. I. (2004) Reinzhynirynh biznes-protsesiv shliakhom informatyzatsii upravlinnia na pidpryiemstvakh Ukrainy [Reengineering of business processes by informatization of management at the enterprises of Ukraine]. Aktualni problemy ekonomiky - Current economic problems. (9) (39): 45-53. [in Ukraine].

8. Mozhlyvi pryntsypy y oriientovani pravyla provedennia administratyvnoho reinzhynirynhu [Possible principles and oriented rules of administrative reengineering]. URL: http:// library.if.ua/book/44/3048.html [in Ukraine].

9. Parkhomenko-Kutsevil O. I. (2013) Suchasni tendentsii rozvytku reinzhynirynhu v systemi derzhavnoho upravlinnia [Current trends in the development of reengineering in public administration]. Efektyvnist derzhavnoho upravlinnia - Efficiency of public administration. Vyp. 36: 20-27. [ in Ukraine]. 
10. Zakon Ukrainy «Pro Natsionalne antykoruptsiine biuro Ukrainy» [Law of Ukraine "On the National Anti-Corruption Bureau of Ukraine"]. URL: https://zakon.rada.gov.ua/laws/show/1698-18. [in Ukraine]. 